\title{
The Impact of Financial Measures, Earnings Management, and Sukuk Structure on Sukuk Rating
}

\author{
Sana Affanadi, ${ }^{1}$ Hina Affandi ${ }^{2}$ \\ ${ }^{1}$ Quaid-i-Azam University, Islamabad \\ ${ }^{2}$ Business and Economics Department, Foundation University, Rawalpindi
}

\begin{abstract}
The impact on sukuk rating imposed by the financial measures, earnings management, and the sukuk structure has been considered by this research study by taking the sample from Pakistan. Financial measures, earnings management, and sukuk structure are the independent variables whereas the sukuk rating is taken as the dependent variable. Financial measures include financial leverage, profitability and issue size; earnings management include the return on assets, firm size and firm age and the sukuk structures undertaken are the musharakah, mudarabah, murabahah and ijarah. This study is conducted on the Pakistani firms that have issued sukuk. Correlation and regression model has been applied. Annual reports of all those firms that issue sukuk which are listed on the rating agency i.e. Pakistan Credit Rating Agency has been taken which has been subject to numerous selection standards. It has been postulated that financial measures, earnings management and sukuk structure have significant influence on sukuk rating and these significant influences have been confirmed by the results of the study. The data has been taken for the period of 2011 to 2015. Ordered logit regression model has been used in this study. Financial measures indicator that is financial leverage has positive influence on sukuk rating whereas profitability and also size of issue i.e. issue size have negative influence on sukuk rating. The indicators of earnings management that are return on assets, firm size and firm age have negative influence on the sukuk rating. Sukuk structure is found to have negative influence on sukuk rating. This study can be further continued by researchers with behavioural finance variables and by keeping control on to the financial measures, earnings management and sukuk structure; sukuk ratings can be improved which would persuade investors to invest in sukuks in Pakistan.
\end{abstract}

Key Words: Financial Measures, Earnings Management, Sukuk Structure, Sukuk Rating

\section{Introduction and Background of the Study}

Practical indications have been found to be documented illustrating that issuance of sukuk plays key roles in ratings of Islamic bonds which are known as sukuk ratings. Sukuk are the essential aspect of the financial framework that effectively fulfil the needs that arise in the banking sector (Sukor, et al. 1970). Apart from banking sectors, other type of industries are also keeping hands on issuing sukuk in markets for fulfilling

Corresponding Author: Sana Afandi, E-mail: sanaaffandi@gmail.com

(c) COMSATS Institute of Information Technology Lahore, Pakistan. 
their credit requirements. According to McMillen (2007), seminal shariah compliant sukuk have been introduced by Europe in the 21st century early years which has augmented the sukuk issuance to retort the investment in the real estate. In the previous studies, development of sukuk market technicalities have been given importance after the occurrence of financial crisis in the South East Asia (Sharma 2001). Under the title " Sukuk Market in Pakistan Set forTake-Off" in the Islamic Economics Project analysis, other than the Muslim countries, non-Muslim majority countries are also involved actively in the sukuk market. Worth of $£ 200$ million sukuk have been issued by the UK treasury. Inadequate and scarce researches on this area of Islamic finance provide the stimulus to do the research that analyses the financial measures, earnings management and sukuk structure impact on sukuk rating respectively by undergoing empirical analysis on the firms operating in Pakistan that issue sukuk.

Islamic financial products provide the impetus to the growth of economy of a country. Shariah compliant products which have been introduced in the banking system and have been used by businesses are benefitting the economic growth and arising the interests of investors in such products. Sukuk provide the possibilities to adapt and explore with the consideration of shariah principles that involve the justice and fair play. Currently, small scale investment needs are fulfilled by the issuance of sukuk that only meet the operational costs. Sukuk meet the requirements of investments that includes the demand and the supply side for fulfilling the financial requirements. In the regulatory treatment, many of the structures of sukuk are considered as the debt structures in the conventional finance perspective. The issuance of sukuk has significant role in the ratings of the Islamic bonds. Because of the market opportunities, Islamic finance has roots specifically in the private equity and the real estate (McMillen, 2007). In this contemporary era, sukuk markets and sukuk are the vital components of the financial framework of many countries that fulfill the needs of the funds based on the principles of Shariah.

To impart the practical and empirical findings on whether there is the significant impact of financial measures, earnings management and the sukuk structure on the sukuk rating respectively or not is the purpose of this research with considering year in which sukuk have been issued, industry which is offering these sukuk and corporate governance quality as control variables. The relationship among the aforementioned independent and dependent variables that are financial measures, earnings management, sukuk structure and sukuk rating have been investigated in this study. Furthermore, the influence of financial measures that include the financial leverage, profitability and issue size on sukuk rating; the influence of earnings management that include return on assets, firm size and firm age on sukuk rating and the influence of sukuk structure that include the murabahah, musharakah, mudarabah and ijarah sukuk on sukuk rating have been highlighted by this research. This research study delivers the empirical results to the firms that issue sukuk in Pakistan. Furthermore, this research is a contribution to the financial system that is Islamic in nature. This research study will also assist in the future researches on the area of Islamic finance will serve different industries that can be benefitted by the issuance of sukuk. 


\section{Literature Review / Theoretical Framework Sukuk Rating Characteristics in Sukuk Markets}

With regard to the AAOIFI perspective, sukuk are defined as the equal value certificates that provide the common shares, rights and stakes in the usufructs, assets that are tangible in nature and services or equity that is associated with an investment activity or in a project (Godlewski, Turk-Ariss \& Weill, 2013). However, sukuk are the Islamic notes which follow the shariah compliance and include the shariah compliant activities. Interest in the case of sukuk refers to the profit and loss that has been shared with the bondholders from investment in some underlying activity. Bond ratings or the credit ratings of a firm are known as sukuk ratings conventionally, and are referred to the future cash flows probability distribution to firms and ultimately to the bondholders, which are provided by the rating agencies. Sukuk ratings are of two types that are for debt issues called as bond ratings or credit issue ratings and financial obligations for sukuk issuance and second for the issuers of debt in the sukuk markets which refers to the credit worthiness (Huang, et al. 2004).

Creditworthiness of a firm refers to the fulfilment of costs related to debt services and principal payment in future (Ashbaugh-Skaife, et al 2006). Study reveals that firms debt policy is influenced by the credit ratings (Graham and Harvey 2001). Moreover, financial leverage has an important determinant i.e. bond market access (Faulkender and Petersen, 2006). Counterparty, default and issuer sukuk ratings have been identified in literature (Huang et al. 2004), in which sukuk ratings that are default has been identified for short period of time whereas counterparty or the issuer sukuk ratings are considered for the extended period of time. Furthermore, rating agencies provide the definition for ratings which do not involve in providing any indication for buying, selling or holding these debt instruments (Altman and Rijken, 2004).

\subsection{Relationship between Financial Measures and Sukuk Rating}

The extent to which the utilization of borrowed money is done by investors is referred as financial leverage and is also called debt ratio which is found by dividing the entire debt by the entire assets (Huang et al. 2004; Vassalou and Xing 2004). Study has indicated that financial leverage and bond ratings are inversely related to each other. Also, antitakeover propositions if found to be strong are related to lower debt financing cost and if antitakeover propositions that are weak then it is related with higher cost of debt financing ${ }^{1}$ (Klock, et al. 2005). Mixed relationships have been found between financial measures, which are also referred in prior studies as financial ratios and sukuk yields or the sukuk ratings. Financial leverage has also been found to have significant negative correlation with the ratings (Ashbaugh-Skaife, et al. 2006). No significant relationship has been found between the financial leverage and bond ratings (Purwaningsih, 2013). A study has also illustrated that financial leverage has no significant influence on the sukuk yields and sukuk ratings (Kilapong and Setiawati, 2015).

Many researchers have used profitability with credit ratings and with its examples (Joh, 2003 and Surkan \& Singleton, 1990). Profitability has been investigated on the basis of

1 The study was conducted originally on two groups in which 34 basis points difference was found. 
risk adjusted and raw portfolio returns, portfolio returns on the basis of adjusted characteristics, stock returns individually and risk adjusted individual stock returns on the basis of asset pricing models which ultimately illustrated that higher raw, risk adjusted and characteristics adjusted returns have been realized by higher rated stocks relative to lower rated stocks (Avramov, et al. 2009). According to Campbell, et al. (2008), Garlappi, et al. (2008) and Dichev (1998), negative relationship between credit risks and returns have been shown by previous researches. Moreover, the relationship between risk and returns associated with credit is found positive that is between distress risk and returns, which is calculated in a study on distance to default (Vassalou and Xing, 2004). According to Kilapong and Setiawati (2015), profitability has been found to have no significant influence on sukuk yields and sukuk ratings. Numerous studies have shown the firm size significance on working capital performance. Firm size has been found to have positive relationship between financial ratios and sukuk yields and sukuk ratings (Kilapong and Setiawati, 2015). Furthermore, it has been found that issue size has no significant influence on the ratings of bonds (Purwaningsih, 2013).

Hypothesis 1: Ceteris Paribas; Financial leverage, Profitability, and Issues Size have significant impact on sukuk ratings.

\subsection{Relationship between earnings management and sukuk ratings:}

According to Shan (2014), Lo and Wong (2011) and Jian and Wong (2010), financial reporting worth has the influence of earnings management via related transactions of third party as preceding studies suggest. Earnings management is done for two incentives which drive the shareholders to involve in earnings management which are inflating earnings to avoid the losses reported and for maintaining listing status and funds raising (Jian and Wong, 2010). This in turn affects the securities demand and ultimately the listings of firms. It has been mentioned in a study that earnings management do not improve the financial reporting quality as the manipulations done by the management through transactions of related party can be observed (Lo and Wong, 2011). According to Paananen and Lin (2009), Barth et al. (2008) and Lang et al. (2006), it has been argued that operationalization of accounting quality has been done by earnings management and value relevance. A study conducted previously has provided an insight into the earnings management model made on the accrual basis. The findings of this research have shown earnings management correlation with the financial performance that is in terms of significance of the financial performance (Dechow, Sloan and Sweeney, 1995). Earnings management tool has been used by firms in which expected and unexpected core earnings are estimated by shifting decreasing income to special items from operating expenses for the purpose of inflating the core earnings (McVay, 2006).

Security valuation and investors' perceptions have been affected by the line item placement in the income statement which is consistent with the behaviour of managers provided by evidences (Bartov \& Mohanram, 2014). Moreover, once this shifting has been done, it is difficult to unscramble them and this learning makes the investors to shift operating expenses reappearance from the next year's original place, to penalize these securities by not investing in them (McVay, 2006). Previous studies have illustrated that financial reporting quality is influenced by related party transactions via

2 These are defined by the AAOIFI standard norm number 17 . 
earning management (Shan, 2014). Eventually, the ratings of the credit issued in the financial markets are affected. Earnings management has been operationalized in terms of return on assets, firm size and firm age (Shan, 2015). Hypothesis that are formulated on the basis of aforementioned literature is as follows:

Hypothesis 2: Ceteris Paribus; Return on assets, firm size and firm age have significant impact on sukuk ratings.

\subsection{Relationship between Sukuk Structure and Sukuk Ratings}

Financial certificates are known as Sukuk which are regarded as equivalent to bond Islamically (Yean 2009). Sukuk ${ }^{2}$ are not the conventional shares or bonds but are defined as the equal value shares which represent ownership of undivided shares in tangible assets, services, specific projects and in the activity related to special investment (Anass 2015). Generally, partial ownership in a debt refers to sukuk murabahah, partial ownership in asset is referred as sukuk al- ijara, project partial ownership as sukuk al musharakah and ownership which is partial in investments made is termed as sukuk alistithmar. Sale of debt with exclusion of selling at the face value has not been tolerable by scholars and has been considered that receivable of debt has been a noticeable proportion (Lahsasna and Lin, 2012).

Hypothesis 3: Ceteris Paribus; Musharakah, Mudarabah, Murabahah and Ijarah Sukuk have significant impact on Sukuk Ratings.

\subsection{Control variables}

Control variables are industry, year dummies, and quality of corporate governance which includes the state ownership concentration, foreign ownership concentration and the supervisory board. Year dummy reflects particular year in which the sukuk have been issued. According to the perspective based upon the theory, firms having good corporate governance are projected to have improvement in the credit ratings. Industry dummy i.e. Industry reflects the industry code of a company in accordance with the industry classification of the Security and Exchange Commission of Pakistan (Shan, 2013). From competitive advantage, it has been found that companies with poor corporate governance, in which the level of corporate governance can be measured by corporate governance ratings or indices, have low credit ratings (Shan, 2015).By considering the corporate governance quality as control variable, the relationship between the other variables of this study can be better understood.

The conceptual model of this research is as follows:

\section{Research Methodology}

The data for this research study has been taken from the sukuk issuing firms' annual financial reports. The companies which are listed on the Stock Exchanges of Pakistan have been considered after undergoing through several selection criteria. Pakistan Credit Rating Agency has been consulted for attaining the rating data for the period of 2010 to 2015. Rating data has been available on the annual basis. Privately owned companies are excluded from the analysis. Only the listed public companies are considered. Data from the five companies have been available for the analysis purpose. 


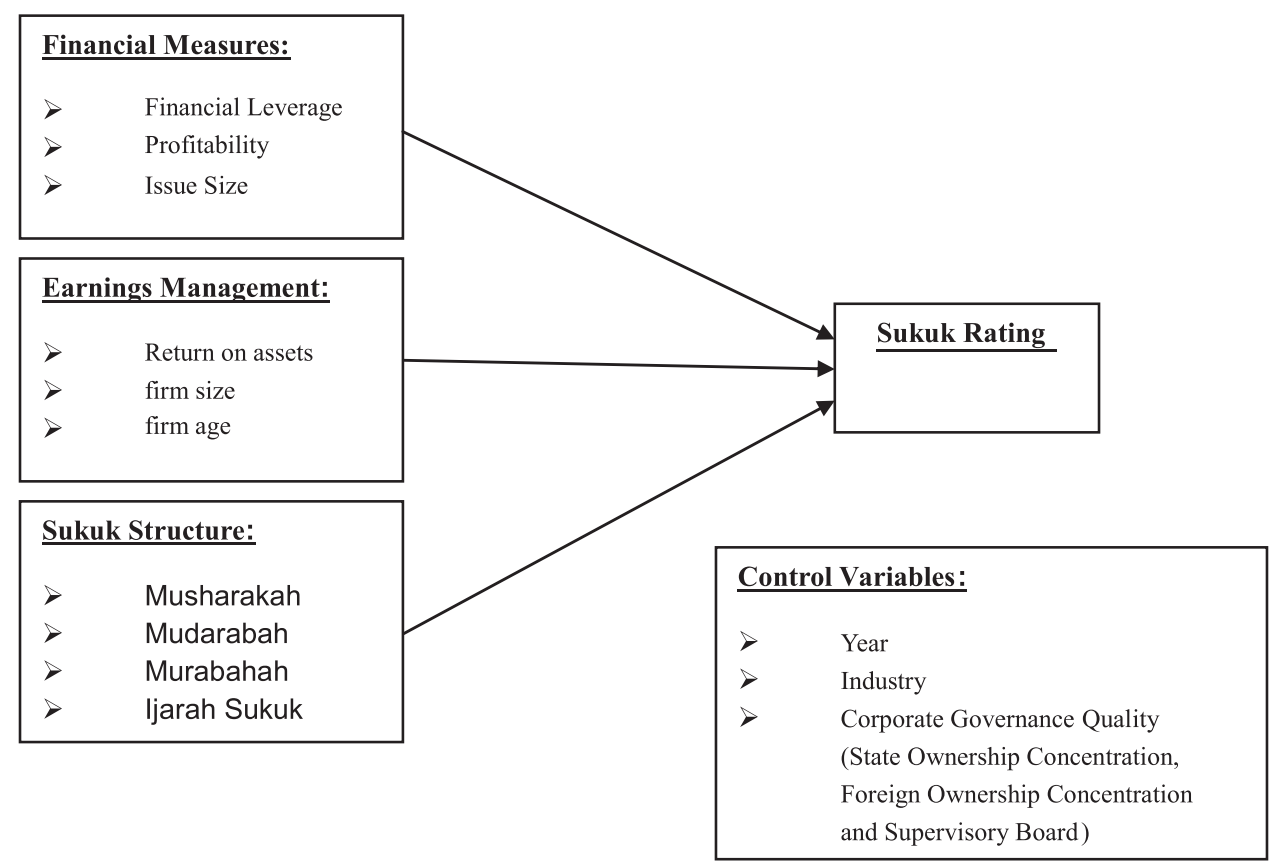

Figure 1 : Conceptual Model

Rating has been assigned as AAA, AA, A and so on in which higher numerical value assigned in this study corresponds to the lower or higher credit rating and vice versa which is similar to a previous research (Hovakimian, et al. 2009). For this study, correlation and ordered logit model has been used (Torres-Reyna 2012). Institutional theory has been utilized for the analysis purpose as a prior study has also used (Abulgasem, Muhamed and Ramli, 2015).

\subsection{Conjecture of Model on the Basis of Conceptual Framework}

It has been found in empirical studies conducted previously that market reactions are influenced by the ratings which bring changes to bond ratings. There have been observed stronger reactions of market to low graded bonds (Goh and Ederington, 1999) which are known as below investment grade bonds as they have more default risk and are considered firms having poor ratings (Hull, et al. 2004) and Purda 2007). So, in this study ordered logit regression model has been used.

\subsection{Ordered Logit Regression model}

The regression model as specified above has been used in which there are categories of dependent variable and by using ordered logit regression model (Torres-Reyna, 2012), the linear equations have been formed, with inclusion of control variables in brackets that are not undergone any operation, which are as follows:

SUKUKR $_{\mathrm{it}}=\mathrm{B}_{\mathrm{o}}+\mathrm{B}_{1} \mathrm{FL}_{\mathrm{it}}+\mathrm{B}_{2} \mathrm{PR}_{\mathrm{it}}+\mathrm{B}_{3} \mathrm{ISSU}_{\mathrm{it}}+\mathrm{e}_{\mathrm{it}}\left(\right.$ Year $_{\mathrm{it}}$, Industry $\left._{\mathrm{it}}, \mathrm{CGQ}_{\mathrm{it}}\right)$ 
SUKUKR $_{\mathrm{it}}=\mathrm{B}_{\mathrm{o}}+\mathrm{B}_{1} \mathrm{ROA}_{\mathrm{it}}+\mathrm{B}_{2} \mathrm{FS}_{\mathrm{it}}+\mathrm{B}_{3} \mathrm{FA}_{\mathrm{it}}+\mathrm{e}_{\mathrm{it}}\left(\right.$ Year $_{\mathrm{it}}$, Industry $\left._{\mathrm{it}}, \mathrm{CGQ}_{\mathrm{it}}\right)$

SUKUKR $_{\mathrm{it}}=\mathrm{B}_{\mathrm{o}}+\mathrm{B}_{1} \mathrm{SS}+\mathrm{e}_{\mathrm{it}}\left(\right.$ Year $_{\mathrm{it}}$ Industry $\left._{\mathrm{it}} \mathrm{CGQ}_{\mathrm{it}}\right)$

Where, firm is mentioned " $\mathrm{i}$ " and time period is given " $\mathrm{t}$ ". Moreover, it refers to error terms in a specific model. SUKUKR is the sukuk rating influenced by FL (financial leverage), PR (profitability) and ISSU (issue size) referred as model 1. In model 2, ROA (return on assets), FS (firm size) and FA (firm age) have been taken. Model 3 is comprised of SS (sukuk structure). Bo is the slope which refers to the constant term. B1 to $\mathrm{B} 3$ refers to the coefficients related to the variables of interest.

\section{Empirical Results, Analysis and Discussion}

Table 1 summarizes and describes the data gathered for this research. The following table illustrates the descriptive statistics which includes financial measures, earnings management and sukuk structure that describe the sukuk ratings.

Table 1: Descriptive Statistics of Research Variables

\begin{tabular}{|l|c|c|c|c|c|c|}
\hline \multicolumn{1}{|c|}{ Variable } & Obs & Median & Mean & Std.Dev & Min & Max \\
\hline Financial Variables & & & & & & \\
Financial Leverage & 25 & 0.89 & 1.13 & 0.80 & 0.08 & 3.29 \\
Profitability & 25 & 0.39 & 0.57 & 0.63 & 0.00 & 2.01 \\
Issue Size & 25 & 4.00 & 5.83 & 3.04 & 2.30 & 9.90 \\
Earnings Management & & & & & & \\
Return on Assets & 25 & 0.88 & 0.30 & 0.50 & 0.00 & 1.99 \\
Firm Size & 25 & 4800 & 5698 & 2752.97 & 2000 & 10,500 \\
Firm Age & 25 & 42.00 & 36.00 & 16.89 & 12.00 & 60.00 \\
Sukuk Structure & & & & & & \\
Musharakah, Mudarabah, & 25 & 2.00 & 2.40 & 1.11 & 1.00 & 4.00 \\
Murabahah, Ijarah Sukuk & & & & & & \\
Control Variables & 25 & 2013 & 2013 & 1.44 & 2011 & 2015 \\
Year & 25 & 3.00 & 3.00 & 1.44 & 1.00 & 5.00 \\
Industry & 25 & 0.10 & 0.15 & 0.14 & 0.00 & 0.40 \\
Corporate Governance Quality & & 23.00 & 23.44 & 5.21 & 15.00 & 30.00 \\
State Ownership & 25 & 1.00 & 0.56 & 0.50 & 0.00 & 1.00 \\
Concentration & & & & & \\
Fore ign Ownership & 25 & 0.22 & 0.19 & 0.11 & 0.00 & 0.35 \\
Concentration & & & & & \\
Supervisory Board & 25 & 25 & & & \\
\hline Sukuk Rating & & & & & \\
\hline
\end{tabular}

Table 1 presents the descriptive statistics for this research study in which for financial variables influence, the average (median) percentage of financial leverage is $89 \%$ 
$(113 \%)$. The standard deviation is $80 \%$ and the lower and the upper quartile value is $8 \%$ and $329 \%$ respectively. The average (median) percentage of sukuk rating held by profitability is $57 \%(39 \%)$, standard deviation is $63 \%$ and the lower and upper quartile is $0 \%$ and $201 \%$ respectively. The average (median) percentage of sukuk rating held by issue size is $4 \%(583 \%)$, standard deviation is $304 \%$ and the lower and upper quartile is $230 \%$ and $990 \%$ respectively. For the influence of earnings management, return on assets mean (median), standard deviation and lower and upper quartile values are $30 \%$ (88\%), $50 \%, 0 \%$ and $199 \%$ respectively. For firm size, mean (median), standard deviation and lower and upper quartile values are $5698 \%, 48 \%, 2752 \%, 20 \%$ and $105 \%$ respectively. For firm age, mean (median), standard deviation and lower and upper quartile values are $36 \%(42 \%), 1689 \%, 12 \%$ and $60 \%$ respectively. For sukuk structure i.e., for musharakah, mudarabah, murabahah and ijarah sukuk, the values of mean (median), standard deviation and lower and upper quartile are $240 \%(200 \%), 111 \%, 100 \%$ and $400 \%$ respectively. The descriptive statistics for control variables are quoted in the table above. Turning to the sukuk rating, mean (median), standard deviation and lower and upper quartile values are $56 \%(100 \%), 50 \%, 0 \%$ and $100 \%$ respectively.

\subsection{Correlation among Variables}

Table 2 presents the correlation among different variables of this research study. The spearman rank order correlation has been determined in this study which are depicted as follows. The correlation among the independent variables that include financial measures, earnings management, sukuk structure, certain control variables and the dependent variable which is sukuk rating has been shown. The significance level has been taken at 0.01 level. Different characteristics of the variables have been taken for each variable as mentioned in the table 2. Variables also have inter-correlations suggesting presence of certain standard errors of coefficients on variables in the ordered logit model.

Research variable of financial leverage only has been seen to have positive effects i.e.

Table 2: Correlation

\begin{tabular}{|l|c|c|c|c|c|c|c|c|c|c|c|c|c|}
\hline & FL & Profit & IS & ROA & FS & FA & SS & Year & IND & SOC & FOC & SB & SR \\
\hline FL & 1 & & & & & & & & & & & & \\
Profit & $-0.17^{*}$ & 1 & & & & & & & & & & & \\
IS & $-0.30^{*}$ & $-0.07^{*}$ & 1 & & & & & & & & & & \\
ROA & $-0.13^{*}$ & $0.36^{*}$ & $0.08^{*}$ & 1 & & & & & & & & & \\
FS & $-0.20^{*}$ & $0.09^{*}$ & $0.31^{*}$ & $0.27^{*}$ & 1 & & & & & & & & \\
FA & $-0.39^{*}$ & $0.04^{*}$ & $0.47^{*}$ & $0.05^{*}$ & $0.50^{*}$ & 1 & & & & & & & \\
SS & $-0.07^{*}$ & $0.22^{*}$ & $0.50^{*}$ & $0.19^{*}$ & $-0.28^{*}$ & $-0.32^{*}$ & 1 & & & & & & \\
Year & $-0.06^{*}$ & $0.40^{*}$ & $0.01^{*}$ & $0.18^{*}$ & $0.11^{*}$ & $0.08^{*}$ & $0.07^{*}$ & 1 & & & & & \\
IND & $0.47^{*}$ & $0.08^{*}$ & $0.81^{*}$ & $0.01^{*}$ & $-0.12^{*}$ & $-0.70^{*}$ & $0.25^{*}$ & $0.00^{*}$ & 1 & & & & \\
SOC & $-0.17^{*}$ & $-0.07^{*}$ & $0.15^{*}$ & $0.01^{*}$ & $0.55^{*}$ & $0.87^{*}$ & $-0.35^{*}$ & $0.01^{*}$ & $-0.29^{*}$ & 1 & & & \\
FOC & $0.09^{*}$ & $-0.10^{*}$ & $0.17^{*}$ & $-0.33^{*}$ & $-0.50^{*}$ & $0.31^{*}$ & $-0.15^{*}$ & $0.04^{*}$ & $-0.10^{*}$ & $0.40^{*}$ & 1 & & \\
SB & $0.13^{*}$ & $-0.03^{*}$ & $0.54^{*}$ & $0.11^{*}$ & $0.22^{*}$ & $-0.33^{*}$ & $-0.40^{*}$ & $0.04^{*}$ & $0.00^{*}$ & $-0.39^{*}$ & $-0.56^{*}$ & 1 & \\
\hline SR & $0.30^{*}$ & $-0.09^{*}$ & $-0.02^{*}$ & $-0.09^{*}$ & $-0.18^{*}$ & $-0.11^{*}$ & $-0.26^{*}$ & $-0.05^{*}$ & $0.17^{*}$ & $0.02^{*}$ & $0.27^{*}$ & $0.18^{*}$ & 1 \\
\hline
\end{tabular}


0.30 which is significant at 0.01 level or below on relationship between financial measures and sukuk rating. Whereas, profitability and issue size are found to have negative effects on the relationship between financial measures and sukuk rating with 0.09 and -0.02 values. Return on assets, firm size, firm age and sukuk structure are also found to have negative relationship between earnings management and sukuk rating with values of $-0.09,-0.18$ and -0.11 and sukuk structure and sukuk rating with value of 0.26 . However, control variables are also found to have significant relationship with sukuk rating as illustrated in the table above. All the aforementioned variables are seen at 0.01 level of significance.

\subsection{Ordered Logit Regression Model Results and Discussion}

This section discusses the effects of financial measures, earnings management and sukuk structure on sukuk rating with inclusion of control variables. Interaction terms have been added in the standard model by using the bivariate methodology. In this research, marginal effects has been seen. In the general model, empirical tests for sukuk rating are derived from the determinant functions of financial measure, earnings management and sukuk structurewhich is adapted from a prior study (HollisAshbaugh, 2004):

Sukuk Rating $=\mathrm{f}($ financial measure, earnings management, sukuk structure)

The following table illustrates the ordered logit regression model results with inclusion of control variables from which following empirical models are extracted of which theoretical models have been mentioned above:

Sukuk Rating $=0.31(\mathrm{FL})+0.00(\mathrm{PR})-0.00(\mathrm{ISSU})$

Sukuk Rating $=-0.00(\mathrm{ROA})-0.07(\mathrm{FS})+0.23(\mathrm{FA})$

Sukuk Rating $=0.07$ (SS)

McFadden $R$ squared value is 0.36 which shows the good model fit and p value is 0.00 which shows influence of independent variables on dependent variables for all the above three empirical models. All the independent variables that are financial measures, earnings management and sukuk structure are found to have influence that is impact on the dependent variable on the basis of coefficients which are significant at 0.01 level or better as illustrated in the following table that is sukuk rating with incorporating the control variables. Moreover, positive relation has been found between financial leverage, profitability, firm age and sukuk structure on sukuk rating. However, negative relation has been found between issue size, return on assets and firm size.

\section{Conclusion}

The basic objective of this research was to dig out whether financial measures, earnings management and sukuk structure have significant influences on sukuk ratings or not. Also, control variables that are year, industry and corporate governance quality are 
COMSATS Journal of Islamic Finance

Table 3: Ordered Logit Regression Model

\begin{tabular}{|c|c|c|c|c|}
\hline \multirow[b]{2}{*}{ Variables } & Predicted & \multicolumn{2}{|c|}{ Estimated Coefficient } & \multirow[b]{2}{*}{ Model-3 } \\
\hline & Sign & Model-1 & Model-2 & \\
\hline \multicolumn{5}{|l|}{ Financial Measures } \\
\hline Financial Leverage & + & $\begin{array}{l}0.31^{* * *} \\
(0.36)\end{array}$ & & \\
\hline Profitability & + & $\begin{array}{l}0.00^{* * *} \\
(0.53)\end{array}$ & & \\
\hline Issue Size & - & $\begin{array}{l}0.00^{* * *} \\
(-0.82)\end{array}$ & & \\
\hline \multicolumn{5}{|c|}{ Earnings Management } \\
\hline Return on Assets & - & & $\begin{array}{l}0.00^{* * *} \\
(-0.00)\end{array}$ & \\
\hline Firm Size & - & & $\begin{array}{l}0.07^{* * *} \\
(-0.37)\end{array}$ & \\
\hline Firm Age & + & & $\begin{array}{l}0.23^{* * *} \\
(0.16)\end{array}$ & \\
\hline Sukuk Structure & + & & & $\begin{array}{r}0.07^{* * *} \\
(0.08)\end{array}$ \\
\hline \multicolumn{5}{|l|}{ Control Variables } \\
\hline Year & & Included & Included & Included \\
\hline Industry & & Included & Included & Included \\
\hline \multicolumn{5}{|c|}{ Corporate Governance Quality } \\
\hline State Ownership C & ntration & Included & Included & Included \\
\hline Foreign Ownership & icentration & Included & Included & Included \\
\hline Supervisory Board & & Included & Included & Included \\
\hline McFadden R-Squar & & 0.36 & Mean & 0.17 \\
\hline Log Likelihood & & -140.96 & Median & 0.16 \\
\hline Skewness & & 0.07 & Jarque-Bera & 1.98 \\
\hline Kurtosis & & 1.62 & Probability & 0.00 \\
\hline
\end{tabular}

taken into consideration for this research study. The sample of this study is the 5 publicly listed Pakistani firms in the stock exchanges of Pakistan for the period of 2011 to 2015. The findings of this study suggest that financial measures indicator that is financial leverage has positive influence on sukuk rating whereas profitability and issue size have negative influence on sukuk rating for the reason that investors intention and perceptions play major role in buying sukuk from markets and ultimately which impact the ratings. The results document that the indicators of earnings management that are return on assets and firm size have negative influence on the sukuk rating whereas firm age has positive influence on the sukuk rating. Sukuk structure is found to have positive influence on sukuk rating.

The results of this research has contribution to the vast knowledge of sukuk rating in literature related to Islamic finance. The current study has definite limitations of simply 
studying certain variables with sukuk rating. This research study can further be undertaken with incorporation of investors behaviours and other external and internal factors for more accurate results. On the basis of ordered logit, the three models which are mentioned above fit with the data and the results are found significant. However, longitudinal study can be done by undertaking the data for ten years which can be robust as well. Moreover, it is recommended that the sukuk ratings should be made shariah compliant and the shariah objectives should be fulfilled by such ratings.

\section{References}

Altman, Edward I and Herbert A Rijken. 2004. "How rating agencies achieve rating stability." Journal of Banking \& Finance 28:2679-2714.

Anass, PATEL. 2015. "Channeling Asset-Managed Sukuk towards SMEs financing: a case study for Sukuk Mudaraba (asset finance) applied to a French SME." European Journal of Islamic Finance.

Ashbaugh-Skaife, Hollis, Daniel W Collins, and Ryan LaFond. 2006. "The effects of corporate governance on firms' credit ratings." Journal of accounting and economics 42:203-243.

Avramov, Doron, Tarun Chordia, Gergana Jostova, and Alexander Philipov. 2009. "Credit ratings and the crosssection of stock returns." Journal of Financial Markets 12:469-499.

Dechow, P. M., \& Schrand, C. 2004. Earnings quality. USA: The Research Foundation of CFA Institute.

Dechow, P. M., Ge, W., \& Schrand, C. 2010. Understanding earnings quality: A review of the proxies, their determinants and their consequences. Journalof Accounting and Economics, $50(2-3), 344-401$.

Dechow, P., M., Sloan, R., G., and Sweeney, A., P. 1995. Detecting Earnings Management. The Accounting Review, Vol. 70, No. 2 (Apr., 1995), pp. 193-225

Elhaj, M., A., A., Muhamed, N., A., and Ramli, N., M. 2015. The Influence of Corporate Governance, Financial Ratios, and Sukuk Structure on Sukuk Rating. Procedia Economics and Finance. 31. $62-74$

Godlewski, C. J., Turk-Ariss, R., \& Weill, L. (2013). Sukuk vs. conventional bonds: A stock market perspective. Journal of Comparative Economics, 41(3), 745-761.

Gunny, K. A. 2010. The relation between earnings management using real activities manipulation and future performance: Evidence from meeting earnings benchmarks. Contemporary Accounting Research, 27(3), 855-888.

Huang, Zan, Hsinchun Chen, Chia-Jung Hsu, Wun-Hwa Chen, and Soushan Wu. 2004. "Credit rating analysis with support vector machines and neural networks: a market comparative study." Decision support systems 37:543-558.

Jordan, J., L., Carlson, C., N., and Wilson, J., R. 1996. Financial indicators measure fiscal health. Journal (American Water Works Association), Vol. 89, No. 8, Optimizing Treatment Processes, pp. 34-40

Kilapong, Greacee Janly Victoria and Lulu Setiawati 2015. "The Effect of Accounting And Nonaccounting Information To The Rating Of Company's Bond."

Lahsasna, Ahcene and Lee Sze Lin. 2012. "Issues in islamic capital markets: Islamic bond/Sukuk." Pp. 495-512 in 3rd International Conference on Business and Economic Research (3rd ICBER 2012) Proceeding.

McMillen, Michael JT. 2007. "Asset securitization sukuk and Islamic capital markets: Structural 
issues in these formative years." Wis. Int'l LJ 25:703.

McVay, S. 2006. Earnings management using classification shifting: An examination of core earnings and special items. The Accounting Review, 81(3),501-531.

Purwaningsih, Septi. 2013. "Faktor Yang Mempengaruhi Rating Sukuk Yang Ditinjau Dari Faktor Akuntansi Dan Non-Akuntansi." Accounting Analysis Journal 2.

Roychowdhury, S. 2006. Earnings management through real activities manipulation. Journal of Accounting and Economics, 42(3), 335-370.

Shaikh, S.,A. \& Saeed, S. SUKUK BOND: The Global Islamic Financial Instrument. MPRA Paper No. 26700, posted 16. November 2010.

Shan, Y.G., 2013. Can internal governance mechanisms prevent asset appropriation? Examination of type I tunneling in China. Corp. Gov. Int. Rev. 21 (3), 225-241.

Sharma, Krishnan. 2001. "The underlying constraints on corporate bond market development in southeast Asia." World development 29:1405-1419.

Sukor, M.E.A., Rusnah M., and Alwin, Y.G., 1970. "Malaysian Sukuk: issues in accounting standard." International Journal of Mechanical and Materials Engineering 16(1):63-71.

Torres-Reyna, Oscar. 2012. "Getting started in Logit and ordered logit regression Princeton University, http://dss.princeton.sdu/training/Logit.pdf.

Vassalou, Maria and Yuhang Xing. 2004. "Default risk in equity returns." The Journal of Finance 59:831-868.

Weston, J.,F. \& Brigham, E.,F. 1985 : Essential of Managerial Finance, Op.Git, P.48.

Yean, Tan Wan. 2009. "Sukuk: Issues and the way forward." International Legal News 6. 